\title{
Penerapan Lembar Kerja Peserta Didik (LKPD) Berbasis Multimedia untuk Meningkatkan Motivasi dan Hasil Belajar Kimia
}

\author{
Munifatun Muthoharoh ${ }^{1},{ }^{*}$, I Made Kirna ${ }^{2}$, Gusti Ayu Indrawati ${ }^{3}$ \\ ${ }^{1}$ Universitas Pendidikan Ganesha \\ 2Universitas Pendidikan Ganesha \\ ${ }^{3}$ SMA Negeri 4 Singaraja
}

\begin{abstract}
Abstrak
Permasalahan dalam penelitian ini adalah masih rendahnya hasil belajar kimia siswa kelas X MIA 3 SMA N 4 Singaraja tahun pelajaran 2016/2017. Masalah lain yang muncul berdasarkan observasi awal yang dilakukan oleh peneliti adalah kurangnya motivasi siswa dalam pembelajaran kimia. Salah satu penyebab rendahnya motivasi siswa adalah keterbatasan penggunaan media dalam proses kegiatan belajar mengajar. Tujuan yang hendak dicapai dalam penelitian ini adalah untuk meningkatkan motivasi dan hasil belajar kimia siswa melalui penerapan LKPD berbasis mutimedia. Guna mencapai tujuan tersebut peneliti melakukan penelitian tindakan kelas yang dilaksanakan dalam dua siklus. Penelitian ini merupakan penelitian tindakan kelas yang dilakukan secara kolaboratif dengan menggunakan model Kemmis dan Taggart. Sbjek penelitian ini adalah siswa kelas X MIA 3 SMAN 4 Singaraja. Metode pengumpulan data dalam penelitian ini adalah angket, tes dan observasi. Instrumen penelitian berupa lembar angket motivasi dan lembar observasi yang dianalisis dengan teknik kualitatif dan dari hasil tes penguasaan konsep yang dianalisis dengan teknik kuantitatif yang dipresentasekan. Hasil penelitian menunjukkan bahwa melalui penerapan LKPD berbasis multimedia dapat meningkatkan motivasi dan hasil belajar kimia siswa kelas X MIA 3 SMAN 4 Singaraja tahun pelajaran 2016/2017. Peningkatan tersebut dapat diketahui dari hasil rata-rata pretest sebelum tindakan dilakukan adalah 45,77 dengan jumlah siswa yang mencapai nilai batas ketuntasan minimal adalah $7,69 \%$, mengalami peningkatan pada siklus I yakni hasil rata-rata tes penguasaan konsep pada siklus I adalah 85,38 dengan jumlah siswa yang mencapai nilai batas ketuntasan minimal adalah $87,18 \%$. Pada siklus II, hasil ratarata penguasaan konsep meningkat menjadi 90,38 dengan persentase jumlah siswa yang nilanya diatas kriteria ketuntasan minimal sebesar 92,31\%.
\end{abstract}

\author{
Kata-kata kunci: \\ Lembar Kerja Peserta Didik \\ (LKPD), multimedia, \\ motivasi, hasil belajar kimia
}

\section{Pendahuluan}

Belajar dalam pendidikan dipandang sebagai usaha sadar dan disengaja yang dirancang dengan baik untuk mencapai tujuan pendidikan. Proses pembelajaran pada hakekatnya diupayakan agar peserta didik dapat mengembangkan aktivitas dan kreativitasnya melalui berbagai interaksi dan pengalaman belajar. Hakikat lain dari pembelajaran adalah perencanaan atau perancangan yang disiapkan guru dalam upaya membelajarkan peserta didik (Mulyasa, 2008:44). Oleh karena itu dalam pembelajaran, diharapkan desain atau rancangan yang disiapkan tidak hanya membuat peserta didik berinteraksi dengan guru sebagai salah satu sumber belajar, tetapi juga dengan keseluruhan sumber belajar yang memungkinkan untuk digunakan dalam upaya mencapai tujuan pembelajaran yang diinginkan.

Pembelajaran yang baik memungkinkan peserta didik dapat berinteraksi dengan guru dan juga lingkungan, sehingga dalam proses pembelajarannya tidak hanya sekedar menghafal sejumlah fakta atau informasi, akan tetapi peristiwa mental dan proses berpengalaman (Sanjaya, 2010:87). Sesuai dengan peraturan pemerintah No. 32 Tahun 2013 pasal 19 dikatakan bahwa "Proses pembelajaran pada satuan pendidikan diselenggarakan secara interaktif, inspiratif, menyenangkan, menantang, memotivasi peserta didik untuk berpatisipasi aktif, serta memberikan ruang yang cukup bagi prakarsa, kreativitas dan kemandirian sesuai dengan 
bakat, minat dan perkembangan fisik serta psikologis peserta didik" (Depdiknas, 2013). Hal ini memperjelas bahwa skenario pembelajaran yang didesain oleh guru harus berorientasi pada kegiatan peserta didik.

Komponen pembelajaran yang berperan penting dalam tercapainya tujuan pembelajaran adalah media pembelajaran, yang merupakan wahana dan penyampaian informasi atau pesan pembelajaran pada peserta didik. Adanya media pada proses belajar mengajar diharapkan dapat membantu guru dalam menyampaikan materi pembelajaran pada peserta didik yang berdampak pada meningkatnya prestasi belajar peserta didik. Oleh karena itu, guru hendaknya menghadirkan media dalam setiap proses pembelajaran demi tercapainya tujuan pembelajaran dan peserta didik semakin aktif dalam proses belajar mengajar (Daryanto, 2010:6). Media adalah suatu pembelajaran yang digunakan dalam rangka lebih mengefektifkan komunikasi dan interaksi antara guru dan siswa dalam proses pendidikan dan pengajaran di sekolah (Oemar Hamalik, 1980:23).

Secara umum media pembelajaran mempunyai kegunaan-kegunaan seperti (1) memperjelas penyajian materi pelajaran agar tidak terlalu bersifat verbalistis (dalam bentuk kata-kata tertulis atau lisan belaka), (2) mengatasi keterbatasan ruang, waktu, dan daya indera, (3) mengatasi sikap pasif pada peserta didik, serta (4) membantu guru mengembangkan bahan pembelajaran dan menambah kesenangan dan minat peserta didik dalam proses pembelajaran. Seiring dengan berjalannya waktu, media pembelajaran juga mengalami perkembangan, karena untuk menutup kelemahan-kelemahan pada media pembelajaran yang telah ada (Sanjaya, 2010:206).

Pada awalnya guru merupakan satusatunya sumber untuk memperoleh pelajaran. Dalam perkembangan selanjutnya, sumber belajar itu kemudian bertambah dengan adanya alat bantu pembelajaran (media pembelajaran) . Perkembangan media pendidikan pada mulanya hanya dianggap sebagai alat bantu mengajar guru yang dipakai adalah alat bantu visual, misalnya gambar, model, objek, dan alat-alat lain yang dapat memberikan pengalaman konkret, motivasi belajar serta mempertinggi daya serap, dan retensi belajar peserta didik. Akan tetapi, karena telalu memusatkan perhatian pada alat bantu visual yang dipakai, guru kurang memperhatikan aspek desain pengembangan pembelajaran produksi dan evaluasinya (Sadiman, 2009:7).

Semakin sadarnya guru akan pentingnya media yang dapat membantu proses pembelajaran sudah mulai dirasakan. Pengelolaan alat bantu pembelajaran sudah sangat dibutuhkan bahkan pertumbuhan ini bersifat gradual. Semakin meluasnya kemajuan di bidang teknologi serta diketemukannya dinamika proses belajar, maka pelaksanaan kegiatan pendidikan dan pengajaran semakin menuntut dan memperoleh media pendidikan yang bervariasi secara luas (Daryanto, 2010:144).

Salah satu media pembelajaran yang dapat digunakan untuk megetahui proses pembelajaran serta aktivitas peserta didik dalam kegiatan belajar mengajar adalah Lembar Kerja Peserta Didik (LKPD). LKPD merupakan tugas yang harus dikerjakan oleh peserta didik. LKPD biasanya berisi petunjuk, langkah-langkah untuk menyelesaikan suatu tugas. Suatu tugas yang diperintahkan dalam LKPD harus jelas kompetensi dasar yang akan dicapainya. LKPD dapat digunakan untuk mata pelajaran apa saja (Depdiknas, 2008). Ratna Wilis Dahar (2001: 29) mengungkapkan bahwa "Lembar Kerja Peserta Didik" (LKPD) adalah lembar kerja yang berisikan informasi dan interaksi dari guru kepada siswa agar dapat mengerjakan sendiri suatu aktifitas belajar, melalui praktek atau penerapan hasil-hasil belajar untuk mencapai tujuan intruksional (perintah).

Dari dua pendapat tersebut dapat disimpulkan bahwa Lembar Kerja Peserta Didik (LKPD) merupakan salah satu media pembelajaran dengan tujuan mengaktifkan siswa, memungkinkan siswa dapat belajar sendiri menurut kemampuan dan minatnya merangsang kegiatan belajar dan juga merupakan variasi pengajaran agar siswa tidak menjadi bosan. LKPD berfungsi untuk menuntun siswa dalam menemukan konsep yang dipelajari, sehinggga pembelajaran bersifat konstruktivis.

Terkait penggunaan media, realita di lapangan berdasarkan observasi di SMA Negeri 4 Singaraja diketahui bahwa LKPD yang biasa digunakan masih berupa media cetak yang didukung dengan alat bantu sederhana yang masih tetap digunakan seperti papan tulis/white board dan spidol. Namun, media audio dan visual dan media elektronik (komputer, LCD, internet) masih belum secara intensif dimanfaatkan. Fasilitas yang terdapat di SMA N 4 Singaraja sudah memadai karena setiap kelas sudah dilengkapi dengan proyektor dan juga layar. Masalah kedua, pemanfaatan media. LKPD dalam bentuk media cetak paling sering digunakan oleh pengajar, karena mudah untuk dikembangkan maupun dicari dari berbagai sumber. Namun, kebanyakan LKPD dalam bentuk ini sangat tergantung pada simbolsimbol verbal (kata-kata) yang bersifat sangat 
abstrak. Hal inilah yang dapat menyulitkan dalam memahami informasi yang terkandung di dalamnya. Oleh karena itu, dalam pemanfaatan media ini diperlukan kreativitas dan juga pertimbangan instruksional yang matang dari pengajar.

Kenyataan yang sering terlihat adalah, banyak pengajar menggunakan media pembelajaran seadanya tanpa pertimbangan materi pelajaran. Pemanfaatan teknologi pembelajaran dengan menciptakan media pembelajaran yang menarik menjadi hal yang harus diperhatikan bagi setiap pengajar, karena aspek ini merupakan aspek penting dalam tercapainya tujuan pembelajaran. Untuk itu teknologi pembelajaran perlu mendapat perhatian dari para guru yang berimplikasi pada penggunaan media pembelajaran yang bervariasi sehingga tercipta suasana belajar yang kondusif, materi pelajaran dapat tersampaikan dengan baik dan tujuan pembelajaran dapat tercapai (Isjoni, 2007:2).

Berdasarkan data hasil pretest peserta didik pada materi pokok kepolaran senyawa, bentuk molekul dan gaya hntar molekul melalui hasil pretest peserta didik kelas X MIA 3, sebagian peserta didik belum mencapai kriteria ketuntasan minimal (KKM) yaitu 67. Nilai ratarata peserta didik sebesar 45,77 dengan persentase nilai di atas KKM yaitu 7,69\% dan persentase nilai di bawah KKM yaitu 92,31\%. Rendahnya hasil pretes di kelas X MIA 3 tersebut menunjukkan bahwa masih rendahnya penguasaan konsep kimia oleh peserta didik.

Hasil wawancara dengan peserta didik tentang permasalahan dalam mata pelajaran kimia, antara lain kesulitan dalam memahami dan menghafal konsep kimia yang abstrak, serta kesulitan mengaitkan konsep dengan kehidupan sehari-hari yang mereka alami. Berdasarkan hasil observasi diketahui bahwa sumber ajar yang digunakan guru adalah buku paket dan LKPD yang disediakan sekolah sehingga informasi yang diperoleh peserta didik juga hanya bersumber pada ketersedian buku-buku kimia di sekolah. Sementara itu, buku paket dan LKPD yang tersedia belum sepenuhnya menuntut peserta didik menemukan pengalaman belajarnya sendiri. LKPD yang tersedia ternyata belum mampu meningkatkan minat peserta didik dalam kegiatan belajar mengajar karena dari segi penampilan dan konten LKPD yang membuat siswa merasa bosan dan malas untuk belajar. Hal ini dapat diketahui dari angket yang diberikan kepada peserta didik, dimana $86 \%$ peserta didik menginginkan adanya LKPD yang menarik yang dapat membangkitkan minta mereka untuk belajar. Dengan didukung adanya fasilitas kelas yang memadai, maka diharapkan LKPD berbasis multimedia flash ini efektif untuk diterapkan dalam kegiatan pembelajaran. Dengan adanya LKPD berbasis multimedia, diharapkan minat siswa untuk belajar terutama dalam mata pelajaran kimia dapat meningkat.

\section{Metode}

Penelitian ini merupakan penelitian tindakan kelas (classroom action research). Penelitian tindakan dalam bidang pendidikan yang dilaksanakan dalam kawasan kelas dengan tujuan untuk memperbaiki dan meningkatkan kualitas pembelajaran. Subyek dalam penelitian ini adalah peserta didik kelas X MIA 3 SMA N 4 Singaraja yang berjumlah 39 peserta didik semester I tahun pelajaran 2016/2017 dengan lokasi penelitian adalah di SMA N 4 Singaraja. Objek dalam penelitian ini adalah motivasi dan hasil belajar peserta didik.

Penelitian ini merupakan penelitian tindakan kelas yang dilaksanakan dalam dua siklus. Alokasi waktu siklus I adalah 4x pertemuan sedangkan siklus II adalah $3 \mathrm{x}$ pertemuan . Siklus I membahas tentang kepolaran senyawa dan bentuk molekul, siklus II membahas gaya antar molekul. Setiap siklus terdiri dari empat tahap yaitu: perencanaan, pelaksanaan tindakan, pengamatan, dan refleksi. Adapun tahapan-tahapannya adalah sebagai berikut: a.Perencanaan. Pada tahap perencanaan ini dilakukan persiapan yang berhubungan dengan pelaksanaan pembelajaran, seperti identifikasi masalah, pembuatan rencana pembelajaran, persiapan lembar kerja peserta didik, pembuatan lembar pengamatan peserta didik dan guru, dan instrumen penilaian. b.

Pelaksanaan Tindakan. Pelaksanaan tindakan merupakan kegiatan dilaksanakannya skenario pembelajaran yang telah direncanakan. Adapun tindakan yang dilakukan oleh guru adalah memberi tugas mandiri kepada peserta didik, membentuk kelompok, membimbing peserta didik dalam diskusi, serta memberikan tes di akhir siklus. c. Pengamatan Pengamatan adalah suatu kegiatan mengamati jalannya pelaksanaan tindakan untuk memantau sejauh mana efek tindakan pembelajaran dengan menerapkan LKPD berbasis multimedia pada pembelajaran kimia. Pengumpulan data pada tahap ini meliputi data motivasi peserta didik dan data nilai hasil belajar peserta didik $\mathrm{d}$. Refleksi. Refleksi berkenaan dengan proses dan dampak yang akan dilakukan. Dengan data observasi, guru dapat merefleksi diri apakah melalui penerapan LKPD ini dapat meningkatkan motivasi dan hasil belajar siswa. Hasil dari refleksi adalah diadakannya perbaikan terhadap perencanaan yang telah dilaksanakan, 
yang akan digunakan untuk memperbaiki kinerja guru pada siklus selanjutnya.

Adapun pelaksanaan proses pembelajaran pada materi pokok kepolaran senyawa dan bentuk molekul melalui penerapan LKPD berbasis multimedia ini terdiri dari empat tahapan tiap siklusnya yang terdiri dari tahap perencanaan, tindakan, observasi dan refleksi yang berulang secara siklis. Apabila pada siklus I masih banyak kekurangan dan belum mendapatkan hasil yang maksimal, maka disempurnakan di siklus berikutnya.

Teknik pengumpulan data yang dilakukan pada penelitian ini ada dua cara yaitu melalui tes dan angket. Tes adalah alat atau prosedur yang digunakan untuk mengetahui atau mengukur sesuatu dalam suasana dengan cara dan aturan-aturan yang sudah ditentukan (Arikunto, 2002:53). Tes digunakan untuk mengukur ada atau tidaknya serta besarnya kemampuan objek yang diteliti. Dalam penelitian ini, tes digunakan untuk mengukur penguasaan konsep peserta didik terhadap konsep yang diajarkan dalam bentuk pilihan ganda dan essay. Untuk mengukur penguasaan konsep peserta didik sebelum mendapat perlakuan penerapan LKPD berbasis multimedia ini dilakukan pretest siklus I yang terdiri dari 20 soal pilihan ganda materi kepolaran senyawa. Selajutnya, posttest diadakan di akhir siklus I dengan soal yang sama. Untuk siklus II, dilakukan tes akhir penguasan konsep setelah pembelajaran menggunakan LKPD berbasis multimedia ini dilaksanakan. Sedangkan Angket merupakan teknik pengumpulan data yang dilakukan dengan cara memberi seperangkat pertanyaan atau pernyataan tertulis kepada responden untuk dijawab (Sugiyono, 2009:142). Angket yang digunakan adalah angket skala Likert dengan memilih 5 jawaban yaitu Sangat Setuju Sekali (SSS), Sangat Setuju (SS), Setuju (S), Tidak Setuju (TS) dan Sangat Tidak Setuju (STS).
Angket ini berisi tentang tanggapan peserta didik terhadap pembelajaran kimia melalui penerapan LKPD berbasis multimedia, motivasi belajar peserta didik, respon peserta didik terhadap tes penguasaan konsep kimia materi kepolaran senyawa, bentuk molekul,gaya antar molekul dan soal-soal yang digunakan dalam penelitian.

Penelitian ini menggunakan metode deskriptif analitis dengan menggunakan daftar nilai kognitif peserta didik. Selanjutnya, data yang diperoleh pada tiap siklus dianalisis secara deskriptif dengan menghitung percentages correction. Menurut Sugiyono (2009) , deskriptif analitis adalah statistik yang digunakan untuk menganalisis data dengan cara mendeskripsikan atau menggambarkan data yang telah terkumpul sebagaimana adanya tanpa bermaksud membuat kesimpulan yang berlaku untuk umum atau generalisasi.

\section{Hasil}

Penelitian tindakan kelas ini dilaksanakan selama 4 minggu mulai tanggal 20 Oktober - 10 November 2016 sebanyak 7x pertemuan dengan total alokasi waktu $11 \times 45$ menit. Data yang diperoleh dari setiap faktor yang diselidiki, dianalisis secara deskriptif analitis dalam bentuk presentase, rata-rata skor pada setiap siklus yang selanjutnya dibahas sesuai tujuan penelitian yang dirumuskan.

Hasil tes penguasaan konsep peserta didik diperoleh dari nilai pretest siklus I, posttest siklus I dan tes akhir siklus II. Pretest digunakan untuk mengetahui kemampuan awal peserta didik sebelum mendapat perlakuan dengan menggunakan media LKPD berbasis multimedia. Soal pretest ini berbentuk pilihan ganda berjumlah 20 soal dengan lima pilihan jawaban. Data hasil pretest ditunjukkan pada Tabel 1 berikut ini:

Tabel 1. Data Hasil Tes Penguasaan Konsep Peserta Didik (Pretest) Siklus I

\begin{tabular}{ccc}
\hline No. & Keterangan & Pretest \\
\hline 1. & Nilai tertinggi & 75 \\
2. & Nilai terendah & 15 \\
3. & Rata-rata & 45,77 \\
4. & \% Ketuntasan klasikal & $7,69 \%$ \\
5. & Kategori & Kurang \\
\hline
\end{tabular}

Berdasarkan Tabel 1 di atas, nilai ratarata peserta didik pada saat sebelum diadakannya pembelajaran dengan menggunakan LKPD berbasis multimedia sebesar 45,77 dengan kategori kurang. Nilai tertinggi yang didapatkan peserta didik yaitu 75 , sedangkan nilai terendahnya 15 . Nilai yang didapatkan masih jauh di bawah Kriteria
Ketuntasan Minimal (KKM) yang sudah ditentukan oleh pihak sekolah yaitu sebesar 67 . Sehingga presentase ketuntasan minimal pada saat pretest ini masih 7,69\% dengan jumlah peserta didik yang tuntas ada 3 orang. Data hasil pretest selengkapnya disajikan pada Lampiran 15. Setelah diadakan pretest, dilaksanakan pembelajaran menggunakan LKPD berbasis 
multimedia selama dua siklus. Postest diadakan di akhir siklus I untuk mengetahui ada tidaknya peningkatan hasil belajar setelah diterapkan pembelajaran menggunakan LKPD berbasis multimedia. Data hasil postes yang sekaligus data siklus I selengkapnya disajikan pada lampiran 16. Deskripsi data hasil tes akhir siklus I sekaligus data postest dapat dilihat pada tabel 2.

Tabel 2 Data hasil Tes Peserta Didik Siklus I (Postest)

\begin{tabular}{ccc}
\hline No. & Keterangan & Siklus I \\
\hline 1. & Nilai tertinggi & 100 \\
2. & Nilai terendah & 50 \\
3. & Rata-rata & 85,38 \\
4. & \% Ketuntasan klasikal & $87,18 \%$ \\
5. & Kategori & Baik \\
\hline
\end{tabular}

Berdasarkan Tabel 2 di atas, nilai ratarata peserta didik pada saat posttest sebesar 85,38 dengan kategori baik. Nilai tertinggi yang didapatkan peserta didik yaitu 100, sedangkan nilai terendahnya 50. Presentase ketuntasan belajarnya sebesar $87,18 \%$.

Selanjutnya diadakan tes akhir siklus II untuk mengetahui ada tidaknya peningkatan penguasaan kosep peserta didik selama diterapkannya LKPD berbasis multimedia ini. Data hasil akhir tes siklus II secara rinci disajikan pada lampiran 17, sedangkan deskripsi data hasil tes akhir siklus II dapat dilihat pada tabel 3 .

Tabel 3 Data Hasil Tes Peserta Didik Siklus II

\begin{tabular}{ccc}
\hline No. & Keterangan & Siklus II \\
\hline 1. & Nilai tertinggi & 100 \\
2. & Nilai terendah & 50 \\
3. & Rata-rata & 90,38 \\
4. & \% Ketuntasan klasikal & $92,31 \%$ \\
5. & Kategori & Baik sekali \\
\hline
\end{tabular}

Dari Tabel 2 dan Tabel 3 diatas, diketahui bahwa nilai rata-rata peserta didik mengalami peningkatan. Hal ini ditunjukkan dari data hasil tes penguasaan konsep kimia peserta didik dengan nilai rata-rata sebesar 85,38 pada siklus I menjadi 90,38 pada siklus II. Presentase ketuntasan belajar peserta didik juga meningkat dari $87,18 \%$ pada Siklus I menjadi $92,31 \%$ pada Siklus II.

Kriteria Ketuntasan Minimal merupakan kriteria yang diberlakukan oleh sekolah untuk menyatakan apakah peserta didik tersebut lulus atau tidak pada satu mata pelajaran. KKM pada mata pelajaran Kimia di SMA N 4 Singaraja yang menjadi tempat penelitian adalah 67. Jumlah peserta didik yang menjadi objek penelitian berjumlah 39. Peserta didik yang tuntas pada pembelajaran dengan menggunakan LKPD berbasis multimedia ini dapat dilihat pada Tabel 4 di bawah ini:

Tabel 4. Presentase Ketuntasan Penguasaan Konsep Kimia Peserta Didik Sebelum dan Setelah diterapkan LKPD Berbasis Multimedia

\begin{tabular}{lccc}
\hline & Keterangan & Tidak Tuntas & Tuntas \\
\hline Pretest & Jumlah Peserta Didik & 36 & 3 \\
& Persentase & $100 \%$ & $7,69 \%$ \\
Siklus I & Jumlah Peserta Didik & 5 & 34 \\
(Postest) & Persentase & $12,82 \%$ & $87,18 \%$ \\
Siklus II & Jumlah Peserta Didik & 3 & 36 \\
& Persentase & $7,69 \%$ & $92,31 \%$ \\
& Rata-rata & $\mathbf{4 0 , 1 7 \%}$ & $\mathbf{6 2 , 3 9 \%}$ \\
\hline
\end{tabular}

Berdasarkan Tabel 4 diatas, dapat diketahui bahwa rata-rata ketuntasan belajar peserta didik setelah diterapkannya LKPD berbasis multimedia pada mata pelajaran kimia ini sebesar 62,39\%. Jumlah peserta didik yang tuntas selalu mengalami kenaikan setiap siklusnya. Pada Siklus I jumlah peserta didik yang tuntas berjumlah 34. Sedangkan 5 orang masih dibawah nilai KKM. Sedangkan pada Siklus II Jumlah peserta didik yang tuntas adalah 36 orang, sedangkan yang belum tuntas 3 orang peserta didik. Hal ini menunjukkan bahwa 
penerapan LKPD berbasis multimedia ini dapat meningkatkan penguasaan konsep peserta didik pada mata pelajaran Kimia materi kepolaran senyawa, bentuk molekul dan gaya antar molekul.

Angket peserta didik digunakan untuk mengetahui motivasi peserta didik terhadap pembelajaran menggunakan LKPD berbasis multimedia sebagai upaya untuk meningkatkan penguasaan konsep peserta didik pada materi kepolaran senyawa, bentuk molekul dan gaya antar molekul. Pengisian angket dilakukan pada akhir pembelajaran tiap akhir siklus oleh semua objek penelitian sebanyak 39 orang. Angket yang digunakan adalah angket skala Likert dengan memilih 5 jawaban yaitu Sangat Setuju Sekali (SSS), Sangat Setuju (SS), Setuju (S), Tidak Setuju (TS) dan Sangat Tidak Setuju (S). Indikator yang digunakan meliputi empat macam yaitu
Attention (Perhatian), Relevance (Relevansi), Confidence (keyakinan/rasa percaya diri siswa), dan Satisfaction (Kepuasan). Kisi-kisi dan bentuk angket motivasi peserta didik dapat dilihat pada Lampiran 6 dan Lampiran 7. Sedangkan perhitungan angket motivasi peserta didik Siklus I dan Siklus II selengkapnya dapat dilihat pada Lampiran 12. Berdasarkan hasil rekapitulasi tersebut diketahui jumlah skor perhitungan pada Siklus I sebesar 1941 dengan nilai rata-rata $61,00 \%$. Sedangkan pada siklus II terjadi peningkatan dengan jumlah skor 2225, dengan nilai rata-rata sebesar 70,00\%. Dengan demikian motivasi peserta didik selalu mengalami peningkatan tiap siklusnya. Adapun deskripsi jumlah skor tiap-tiap indikatornya pada Siklus I dan Siklus II dapat dilihat pada Tabel 4.6 dan Tabel 5 di bawah ini:

Tabel 5. Persentase Tiap Indikator Angket Motivasi Peserta Didik Pada Siklus I

\begin{tabular}{llcc}
\hline \multicolumn{1}{c}{ Indikator } & \multicolumn{1}{c}{ Nomor item } & Skor & Persetase (\%) \\
\hline Perhatian & $1,3,5,12,14,18,24,27$ & 506 & 63 \\
Relevansi & $4,6,8,10,23,26$ & 380 & 48 \\
Percaya Diri & $7,9,11,16,20,22,25,29$ & 544 & 68 \\
Kepuasan & $2,13,15,17,19,21,28,30$ & 511 & 64 \\
& Jumlah & $\mathbf{1 9 4 1}$ & $\mathbf{2 4 3}$ \\
& Rata-rata & $\mathbf{4 8 5}$ & $\mathbf{6 1 , 0 0 \%}$ \\
\hline
\end{tabular}

Tabel 6. Persentase Tiap Indikator Angket Motivasi Peserta Didik Pada Siklus II

\begin{tabular}{llcc}
\hline \multicolumn{1}{c}{ Indikator } & \multicolumn{1}{c}{ Nomor item } & Skor & Persetase (\%) \\
\hline Perhatian & $1,3,5,12,14,18,24,27$ & 587 & 73 \\
Relevansi & $4,6,8,10,23,26$ & 441 & 55 \\
Percaya Diri & $7,9,11,16,20,22,25,29$ & 611 & 76 \\
Kepuasan & $2,13,15,17,19,21,28,30$ & 586 & 73 \\
& Jumlah & $\mathbf{2 2 2 5}$ & $\mathbf{2 7 8}$ \\
& Rata-rata & $\mathbf{5 5 6}$ & $\mathbf{7 0 , 0 0 \%}$ \\
\hline
\end{tabular}

Berdasarkan Tabel 5 dan 6 diatas diketahui bahwa motivasi peserta didik selalu mengalami peningkatan. Hal ini ditunjukkan oleh peningkatan jumlah skor tiap indikatornya. Rerata jumlah skor angket motivasi peserta didik meningkat dari $61 \%$ pada Siklus I menjadi $70 \%$ pada Siklus II. Dengan demikian pembelajaran melalui penerapan LKPD berbasis multimedia pada materi kepolaran senyawa, bentuk molekul dan gaya antar molekul ini mampu meningkatkan motivasi peserta didik.

Observasi digunakan untuk mengetahui tahap-tahap kegiatan/aktivitas peserta didik dalam proses belajar mengajar. Bentuknya berupa lembar observasi kompetensi sikap sosial yang sudah dirinci menampilkan aspekaspek dari proses yang harus diamati. Penilaian sikap sosial peserta didik yang diamati pada siklus I dan siklus II meliputi aspek: memperhatikan penjelasan guru, menjawab pertanyaan, keaktifan dalam diskusi kelompok, kerjasama dan kemampuan menjawab pertanyaan.

Secara lebih rinci rekapitulasi lembar observasi aktivitas sosial terdapat pada lampiran 13. Pada Tabel 4.8 dan Tabel 4.9 di bawah ini disajikan hasil observasi aktifitas peserta didik siklus I dan siklus II. 
Tabel 7 Rekapitulasi Observasi Aktivitas Peserta Didik Siklus I

\begin{tabular}{clcc}
\hline No. & \multicolumn{1}{c}{ Kriteria } & Total Skor & Persentase (\%) \\
\hline 1 & $\begin{array}{l}\text { Memperhatikan penjelasan } \\
\text { dari guru }\end{array}$ & 123 & 79 \\
2 & $\begin{array}{l}\text { Menjawab pertanyaan dari } \\
\text { guru }\end{array}$ & 120 & 77 \\
3 & $\begin{array}{l}\text { Aktif berdiskusi dalam } \\
\text { kelompok }\end{array}$ & 120 & 77 \\
4 & $\begin{array}{l}\text { Kerjasama dalam kelompok } \\
5\end{array}$ & 117 & 75 \\
$\quad \begin{array}{l}\text { Keaktifan bertanya siswa } \\
\text { dalam KBM }\end{array}$ & 111 & 71 \\
$\quad \begin{array}{l}\text { Rata-rata } \\
\text { Kategori }\end{array}$ & 118,2 & Baik \\
\hline
\end{tabular}

Tabel 8. Rekapitulasi Observasi Aktivitas Peserta Didik Siklus II

\begin{tabular}{clcc}
\hline No. & \multicolumn{1}{c}{ Kriteria } & Total Skor & Persentase (\%) \\
\hline 1 & $\begin{array}{l}\text { Memperhatikan penjelasan } \\
\text { dari guru }\end{array}$ & 122 & 78 \\
2 & $\begin{array}{l}\text { Menjawab pertanyaan dari } \\
\text { guru }\end{array}$ & 119 & 76 \\
3 & $\begin{array}{l}\text { Aktif berdiskusi dalam } \\
\text { kelompok }\end{array}$ & 121 & 78 \\
4 & Kerjasama dalam kelompok & 125 & 80 \\
5 & $\begin{array}{l}\text { Keaktifan bertanya siswa } \\
\text { dalam KBM }\end{array}$ & 122 & 78 \\
$\quad$ & $\quad$ Rata-rata & 121,8 & $78,08 \%$ \\
& $\quad$ Bategori & \multicolumn{2}{c}{} \\
\hline
\end{tabular}

Berdasarkan Tabel 7 dan Tabel 8 di atas, Terdapat peningkatan aktivitas peserta didik. Hal tersebut ditunjukkan oleh jumlah rata-rata penilaian sikap sosial pada siklus I yaitu 118,2 dengan persentase sebesar 75,77\% dan kategori cukup. Sedangkan jumlah rat-rata penilaian sikap social pada siklus II adalah 121,8 dengan persentase sebesar $78,08 \%$ dengan kategori baik. Dengan demikian pembelajaran melalui penerapan LKPD berbasis multimedia ini mampu meningkatkan aktivitas peserta didik tiap siklus.

\section{Pembahasan}

Penguasaan konsep peserta didik

Berdasarkan data hasil penelitian diatas, perbandingan nilai rata-rata hasil tes penguasaan konsep Kimia peserta didik pada materi kepolaran senyawa, bentuk molekul dan gaya antar molekul sebelum dan sesudah diterapka $\mathrm{n}$ pembelajaran menggunakan LKPD berbasis multimedia pada materi kepolaran, bentuk molekul dan gaya antar molekul selalu mengalami peningkatan. Pretest yang dilaksanakan sebelum pembelajaran bertujuan untuk mengetahui pengetahuan awal peserta didik mengenai bahan yang disajikan. Nilai rata-rata pretest sebelum diterapkannya pembelajaran menggunakan LKPD berbasis multimedia sebesar 45,77 yang tersebar diantara nilai tertinggi 75 dan nilai terendah 15. Dari data tersebut dapat dilihat bahwa nilai ratarata pretest masih berada di bawah kriteria nilai ketuntasan minimum yaitu 67.

Hasil rata-rata pretest yang cenderung rendah dan berada di bawah nilai KKM dapat disebabkan oleh ketidaksiapan peserta didik. Dalam proses belajar, adanya kesiapan tersebut mempengaruhi hasil belajar peserta didik. Peserta didik yang siap belajar akan menghasilkan nilai yang baik dibandingkan dengan peserta didik yang tidak memiliki kesiapan untuk belajar. Peserta didik tidak memiliki kesiapan belajar dikarenakan dalam setiap proses belajar mengajar tidak pernah mendapatkan pretest dari guru yang bersangkutan sehingga peserta didik tidak pernah membaca atau belajar terlebih dahulu sebelum materi disampaikan. Faktor lain yang mempengaruhi adalah kesulitan peserta didik dalam mengerjakan soal tes yang diberikan, karena materi yang terdapat didalam soal pretest belum pernah didapatkan sebelumnya. Sehingga nilai pretest yang didapatkan berada di bawah nilai KKM yang telah ditentukan.

Penelitian ini terdiri dari dua siklus, dimana setiap siklus terdiri dari empat tahapan utama yaitu tahap perencanaan, tindakan, observasi dan refleksi yang berulang secara siklis. Siklus I maupun siklus II terbagi menjadi tujuh kali 
pertemuan dengan total alokasi waktu 11 x 45 menit. Materi yang disampaikan tiap pertemuan disajikan dalam Tabel 4.1 di atas. Penelitian ini mengacu pada pembelajaran menggunakan LKPD berbasis multimedia. Kegiatan pembelajaran dengan menggunakan LKPD berbasis multimedia dilaksanakan dengan menggunakan pendekatan saintifik siklus $5 \mathrm{M}$ yaitu mengamati, menanya, mengumpulkan informasi, mengasosiasi dan mengomunikasikan.

Pada tahap megamati, peserta didik ditugaskan untuk mengamati dan mencermati ringkasan isi yang disajikan pada flash player yang ditayangkan secara online di depan kelas. Peserta didik juga mengamati presentasi ringkasan materi oleh guru di depan kelas. Informasi-informasi penting yang diperoleh dicatat sebagai informasi awal yang diterima peserta didik. Selain pengamatan pada ringkasan isi, peserta didik juga melakukan pengamatan pada video yang terdapat dalam LKPD. Video yang diamati digunakan sebagai salah satu sumber untuk membuat rumusan masalah terkait materi yang akan dipelajari oleh peserta didik. Selanjutnya, pada tahap menanya peserta didik membuat rumusan masalah berdasarkan video, fenomena, tabel maupun grafik yang telah diamati. Rumusan masalah yang diajukan selalu mengarah pada tujuan pembelajaran yang hendak dicapai. Kegiatan menanya bertujuan untuk melatih siswa mengembangkan kreativitas, rasa ingin tahu, kemampuan merumuskan pertanyaan untuk membentuk pikiran kritis yang perlu untuk hidup cerdas. Tahap pengumpulan data, peserta didik mengumpulkan data sebanyak-banyaknya melalui studi literatur dan diskusi kelompok agar dapat menjawab rumusan masalah yang telah diajukan. Selanjutnya pada fase asosiasi, LKPD yang berisi materi flash dan video yang telah disajikan dalam fase pengamatan, juga berisi pertanyaan-pertanyaan yang harus didiskusikan secara berkelompok. Siswa dalam kelompok masing-masing harus berberan aktif dan bekerjasama untuk dapat menyelesaikan pertanyaan terkait materi yang dipelajari. Pertanyaan yang telah didiskusikan, selanjutnya dipresentasikan di depan kelas oleh masingmasing kelompok. Di sini, guru berberan sebagai fasilitator yang memfasilitasi Tanya jawab kelompok. Guru juga berperan memberikan penguatan agar siswa tidak mengalami miskonsepsi terhadap apa yang telah mereka pelajari. Mengkomunikasikan melatih siswa mengembangkan sikap jujur, teliti, toleransi, kemampuan berpikir sistematis, mengungkapkan pendapat dengan singkat dan jelas, dan mengembangkan kemampuan berbahasa yang baik dan benar.

Pada akhir siklus I, peserta didik diberikan tes penguasaan konsep Kimia berupa tes pilihan ganda sebanyak 20 butir pertanyaan. Deskripsi hasil tes penguasaan konsep Kimia pada siklus I ini disajikan pada Tabel 4.3 diatas. Berdasarkan Tabel 4.3 tersebut diketahui bahwa nilai rata-rata tes penguasaan konsep peserta didik sebesar 85,38 dengan nilai tertinggi 100 dan nilai terendah 50. Persentase ketuntasan klasikal pada siklus ini sebesar 87,18\% dengan kategori baik.

Tes akhir siklus I juga merupakan postes dengan tujuan untuk megetahui penguasaan konsep peserta didik atas materi yang sudah diajarkan pada siklus I melalui penerapan LKPD berbasis multimedia. Nilai ratarata posttest peserta didik adalah 85,38 yang tersebar diantara nilai tertinggi 100 dan nilai terendah 50. Berdasarkan data yang telah diperoleh, terdapat perbedaan nilai rata-rata pretest dan posttest sebesar 39,61. Nilai pretest dan posttest dijadikan sebagai bahan perbandingan untuk mengetahui pengaruh LKPD berbasis multimedia yang digunakan selama pembelajaran. Perbedaan atau selisih antara nilai pretest dan posttest merupakan pencapaian yang nyata sebagai pengaruh dari proses belajar peserta didik. Oleh Karena itu, kegiatan pembelajaran melalui penerapan LKPD berbasis multimedia ini memberikan pengaruh yang baik terhadap penguasaan konsep kimia peserta didik karena rata-rata nilai posttest jauh lebih besar daripada rata-rata nilai pretest.

Perbandingan nilai rata-rata penguasaan konsep peserta didik sebelum dan sesudah diterapkan pembelajaran menggunakan LKPD berbasis multimedia disajikan dalam gambar 4.1 berikut ini:

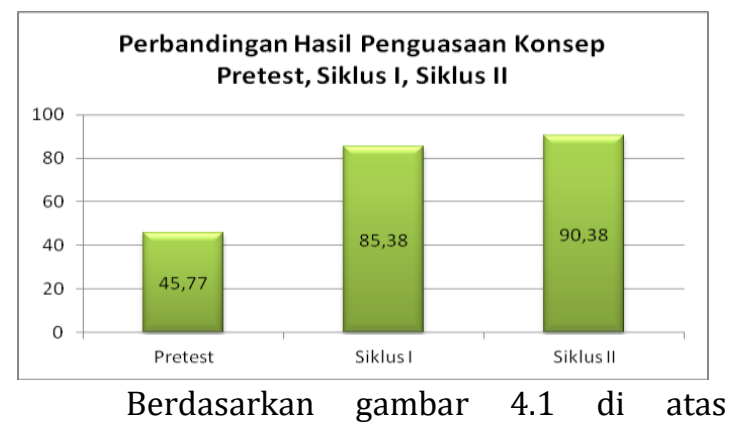

menunjukkan adanya perbedaan yang signifikan dalam peningkatan penguasaan konsep kimia yang dicapai peserta didik. Peningkatan penguasaan konsep yang dicapai peserta didik menggambarkan peningkatan pemahaman masing-masing peserta didik tentang konsep yang telah dipelajari. Berdasarkan gambar $4.1 \mathrm{di}$ atas, memperlihatkan nilai rata-rata pretest sebesar 45,77, nilai rata-rata siklus I sebesar 
85,38 dan siklus II sebesar 90,38. Hal ini menunjukkan bahwa rata-rata kemampuan penguasaan konsep kimia peserta didik mengalami peningkatan setelah siklus I.

Pada akhir siklus II ini, peserta didik mendapatkan tes penguasaan konsep Kimia. Deskripsi hasil tes penguasaan konsep Kimia pada siklus II disajikan pada Tabel 4.4 diatas.

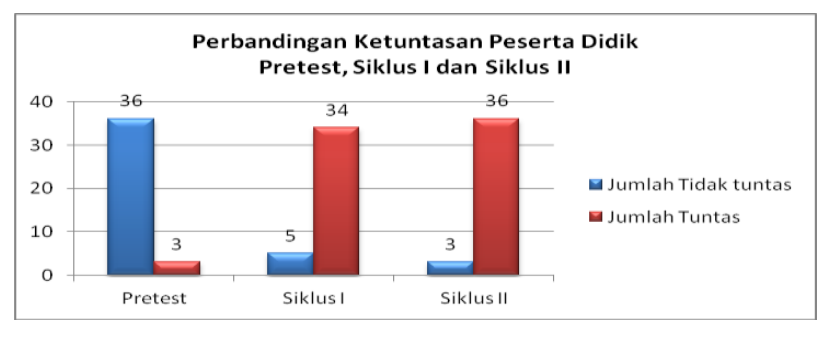

Berdasarkan Tabel 4.4 tersebut diketahui bahwa nilai rata tes penguasaan konsep peserta didik pada siklus II sebesar 90,38 dengan nilai tertinggi 100 dan nilai terendah 50. Persentase ketuntasan klasikal yang diperoleh sebesar 92,31\% dengan kategori baik sekali. Kriteria Ketuntasan Minimal merupakan kriteria yang diberlakukan oleh sekolah untuk menyatakan apakah peserta didik tersebut lulus atau tidak pada satu mata pelajaran. KKM pada mata pelajaran Kimia di SMA N 4 Singaraja yang menjadi tempat penelitian adalah 67. Jumlah peserta didik yang menjadi objek penelitian berjumlah 39 . Perbandingan ketuntasan belajar peserta didik pada pembelajaran dengan menggunakan LKPD berbasis multimedia ini dapat dilihat pada Gambar 4.2 di bawah ini:

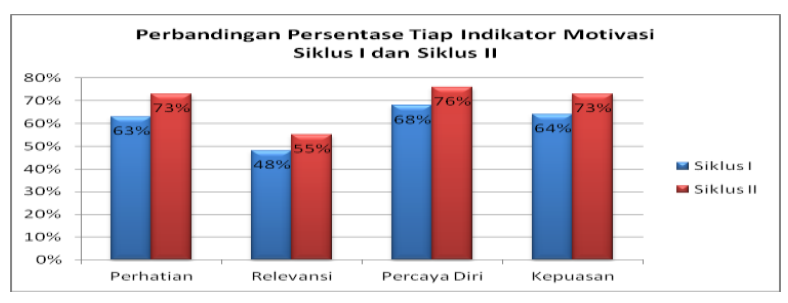

Berdasarkan Gambar 4.2 di atas, dapat diketahui bahwa rata-rata ketuntasan belajar peserta didik setelah diterapkannya LKPD berbasis multimedia sebesar 62,39\%. Jumlah peserta didik yang tuntas selalu mengalami kenaikan setiap siklusnya. Pada Siklus I jumlah peserta didik yang tuntas berjumlah 34 . Sedangkan 5 orang masih berada dibawah nilai KKM. Sedangkan pada Siklus II Jumlah peserta didik yang tuntas adalah 36 orang, sedangkan yang belum tuntas 3 orang peserta didik. Hal ini menunjukkan bahwa penerapan LKPD berbasis multimedia dapat meningkatkan penguasaan konsep peserta didik pada mata pelajaran Kimia kepolaran senyawa, bentuk molekul dan gaya antar molekul.

\section{Angket motivasi peserta didik}

Pembelajaran melalui penerapan LKPD berbasis multimedia pada materi kepolaran senyawa, bentuk molekul dan gaya antar molekul membuat peserta didik termotivasi untuk aktif dalam pembelajaran. Melalui LKPD berbasis multimedia ini, peserta didik dihadapkan langsung dengan animasi flash player yang menyajikan konsep kimia mulai dari makroskopik, simbolik hingga mikroskopis. Dengan demikian, peserta didik mampu mengkonstruksi konsep yang abstrak sehingga mudah dipahami melalui media presentasi flash player. Berdasarkan data yang disajikan pada Tabel 4.6 dan Tabel 4.7 menunjukkan adanya peningkatan motivasi peserta didik dari siklus I ke siklus II. Perbandingan presentase tiap-tiap indikator angket tanggapan peserta didik pada siklus I dan siklus II disajikan pada Gambar 4.3 berikut ini: Berdasarkan Gambar 4.3 diatas menunjukkan bahwa motivasi peserta didik selalu mengalami peningkatan tiap siklusnya. Presentase pada kategori attention (perhatian) meningkat dari $63 \%$ pada siklus I menjadi $73 \%$ pada siklus II. Pada kategori relevantion(Relevansi) meningkat dari 48\% pada siklus I menjadi 55\% pada siklus II, untuk kategori confidence(Percaya diri) meningkat dari $68 \%$ pada siklus I menjadi $76 \%$ pada siklus II dan pada kategori satisfaction(kepuasan) terjadi peningkatan dari 64\% pada siklus I menjadi $73 \%$ pada siklus II. Nilai angket motivasi peserta didik pada siklus I ini rendah dibandingkan dengan siklus II disebabkan pada siklus I peserta didik belum aktif dalam kegiatan belajar mengajar, peserta didik belum terbiasa dengan pembelajaran menggunakan LKPD berbasis multimedia ini, sehingga pada saat awal penerapan LKPD berbasis multimedia sebagai media presentasi ini banyak yang masih kebingungan karena jarang menggunakan flash player. Namun pada siklus II sudah terjadi peningkatan karena peserta didik sudah terbiasa berinteraksi dengan multimedia sehingga pada saat pembelajaran berlangsung keaktifan peserta didik mulai ada peningkatan.

\section{Observasi aktivitas peserta didik dalam pembelajaran}

Data aktivitas peserta didik selama pembelajaran diperoleh melalui observasi menggunakan lembar observasi. Berdasarkan hasil observasi aktivitas peserta didik, tampak bahwa melalui penerapan LKPD berbasis multimedia ini mampu meningkatkan keaktifan peserta didik dari siklus I ke siklus II. Hal itu ditunjukkan oleh kenaikan rata-rata aktivitas 
sebesar 75,77\% dengan kategori baik pada siklus I menjadi 78,08\% pada siklus II dengan kategori baik. Pada siklus I peserta didik tampak aktif dan antusias dalam kegiatan belajar mengajar, hal ini ditandai oleh peserta didik yang mampu mengungkapkan pertanyaan kepada guru, peserta didik tidak malu untuk bertanya ataupun menanggapi pertanyaan. Pada siklus II, aktivitas peserta didik mengalami peningkatan. Hal ini ditandai dengan kenaikan persentase aktivitas peserta didik pada siklus II. peserta didik sudah terbiasa menggunakan LKPD berbasis multimedia ini sehingga terjadi peningkatan keseriusan dalam memperhatikan animasi flash player yang ditayangkan sebagai media presentasi, kekompakan dalam kegiatan diskusi dan keaktifan mereka dalam mengerjakan tugas diskusi.

\section{Penutup}

Berdasarkan data angket motivasi peserta didik, pembelajaran melalui penerapan LKPD berbasis multimedia pada materi kepolaran senyawa, bentuk molekul dan gaya antarmolekul ini mampu meningkatkan motivasi peserta didik. Hal ini ditunjukkan oleh data angket motivasi peserta didik pada siklus I dengan rata-rata persentase motivasi sebesar 61,00\% dengan kategori kuat. Sedangkan persentase angket motivasi peserta didik pada siklus II sebesar $70,00 \%$ dengan kategori kuat. Pada lembar observasi aktivitas terdapat peningkatan ratarata aktivitas peserta didik dari 75,77\% dengan kategori baik pada siklus I menjadi 78,08\% dengan kategori baik pada siklus II.

Penerapan LKPD berbasis multimedia pada materi kepolaran senyawa, bentuk molekul dan gaya antarmolekul ini dapat meningkatkan penguasaan konsep kimia peserta didik kelas $\mathrm{X}$ MIA 3 SMAN 4 Singaraja. Hal ini ditandai oleh adanya peningkatan rata-rata penguasaan konsep peserta didik yaitu dari 45,77 pada pra siklus (pretest) dengan kategori kurang dengan presentase ketuntasan belajar sebesar 7,69\% meningkat menjadi 85,38 pada siklus I dengan presentase ketuntasan $87,18 \%$. Sedangkan pada siklus II rata-rata penguasaan konsep kimia peserta didik sebesar 90,38 dengan presentase ketuntasan belajar sebesar 92,31\%. Dengan demikian dari hasil penelitian dan pembahasan dapat disimpulkan bahwa pembelajaran melalui penerapan LKPD berbasis multimedia ini dapat meningkatkan motivasi dan penguasaan konsep kimia peserta didik.
Daftar Pustaka

Arikunto, Suharsimi. 2002. Dasar-Dasar Evaluasi Pendidikan (edisi revisi), Jakarta: Bumi Aksara.

Dahar Ratna Wilis. 2001. Media Penunjang Pembelajaran. Jakarta : Bumi Aksara.

Depdiknas, 2008. Panduan Pengembangan Bahan Ajar. Jakarta : Direktorat Jenderal Manajemen Pendidikan Dasar dan Menengah

Echols, John M. dan Hasan Shadily. 2003. Kamus Inggris-Indonesia. Jakarta: PT. Gramedia.

Hamalik, Oemar. 1980. Jenis-Jenis Media Pembelajaran. Bandung : PT. Remaja Rosda Karya

Iskandar. 2009. Psikologi Pendidikan (Sebuah Orientasi Baru), Ciputat: Gaung Persada Indah.

Mc. Taggart, R dan Kemmis, S. 1990. The Action Research Planner. Melbourne. Deakin University.

Mulyasa. 2008. Implementasi Kurikulum Tingkat Satuan Pendidikan. Jakarta : Bumi Akasara.

Permendiknas. 2013. Standar Kompetensi Lulusan Untuk Satuan Pendidikan Dasar dan Menengah. (online : http://www.puskur.net/) Diakses pada tanggal 20 Juli 2016.

Permendiknas. 2013. Peraturan Pemerintah RI.No. 32 Th 2013.

Sadiman. 2009. Media Pembelajaran Interaktif. Jakarta : Erlangga

Sanjaya, Wina. 2010. Strategi Pembelajaran Berorientasi Standar Proses Pendidikan. Jakarta : Kencana Prenada Media

Soemanto, Wasty. 20054. Psikologi Pendidikan, Jakarta: PT Rineka Cipta.

Sudjana, Nana. 2012. Penilaian Hasil Proses Belajar Mengajar. Bandung: PT. Remaja Rosda Karya

Sugiyono. 2010. Metode Penelitian Kuantitatif Kualitatif dan R\&D. Bandung : Alfabeta.

Sukardjo dan Komarudin, Ukim. 2009. Landasan Pendidikan Konsep dan Aplikasinya, Jakarta: Rajawali Press.

Suprijono, Agus. 2010. Cooperative Learning Teori dan Aplikasi PAIKEM, Yogyakarta: Pustaka Pelajar.

Suryabrata, Sumadi. 2008. Psikologi Pendidikan. Jakarta : Grafindo Persada

Syaiful Bahri Djamarah. 2008. Psikologi Belajar, Jakarta: Rineka Cipta. 